\title{
Introduction: Eco-Fictions, The Animal Trope and Irish Studies
}

\author{
Margarita Estévez-Saá \\ Manuela Palacios-González \\ Noemí Pereira-Ares \\ Universidade de Santiago de Compostela, Spain
}

Copyright (c) 2020 by Margarita Estévez-Saá, Manuela Palacios-González and Noemí Pereira-Ares. This text may be archived and redistributed both in electronic form and in hard copy, provided that the authors and journal are properly cited and no fee is charged for access.

Nature, animals, the landscape and the environment have enjoyed a recurrent presence and have indeed been constant protagonists in Irish literature and culture. The wild isolated island, originally feared or even despised by foreigners, progressively became that romanticised, premodern Arcadia imagined by tourists from the early twentieth century onwards. The once desolated and barren landscapes of the Great Hunger were imaginatively recreated as green pastures, nostalgically conjured up by nineteenth- and twentieth-century Irish emigrants across the world. More recently, during the decades of the economic boom, the Irish land of the Celtic Tiger was plundered mercilessly by unscrupulous property developers, and its historical sites and natural resources were appropriated as commodities for tourism. These are just some examples of the many uses and abuses of the Irish environment in the recent cultural history of the island.

One might expect that the development of Green Studies, Deep Ecology, Ecofeminism(s), Ecocriticism, Ecofeminist Literary Criticism and Animal Studies would, in this sense, be drawn especially to Ireland, yet this has not been the case. Whereas such conceptual frameworks emerged in the late seventies and early eighties, the consolidation of their bases, principles and values in the 1990s, as well as the development of their methodologies, coincided with the years of the Celtic Tiger, when Ireland and the Irish were being carried on a tide of economic prosperity which would have disastrous consequences, although these were only discerned by a small number of artists and intellectuals. Hence, the much-needed revision of and deep reflection on ecology and the environment in Ireland came only after the economic collapse of 2008. This was made manifest through the publication of representative works such as, among others, Terry Gifford's Emerald Green: An Ecocritical Study of Irish Literature (2009), Christine Cusick's collection Out of the Earth: Ecocritical Readings of Irish Texts (2010), Eóin Flannery, Ireland and Ecocriticism: Literature, History and Environmental Justice (2018) and Donna Potts's Contemporary Irish Writing and Environmentalism. The Wearing of the Deep Green (2018). Animal Studies and the study of the representation of nonhuman creaturely life is also beginning to gain force thanks to 
pioneer analyses such as the ones offered by Maureen O'Connor in The Female and the Species. The Animal in Irish Women's Writing (2010) and Kathryn Kirkpatrick and Borbála Faragó in Animals in Irish Literature and Culture (2015).

The aim of the XVII International AEDEI Conference "Eco-Fictions and Irish Studies", celebrated in Santiago de Compostela in May 2018, was precisely to stimulate further critical debate on the Irish environment as configured by Irish literature and culture, since, as Eóin Flannery among others had observed, "the field of Irish cultural studies has yet to exploit fully the critical and analytical resources of ecological criticism" (2012: 6).

This special issue of Estudios Irlandeses on "Eco-Fictions, The Animal Trope and Irish Studies" was conceived under the auspices of that Conference and sponsored by the research projects "Eco-Fictions: Emergent Discourses on Women and Nature in Ireland and Galicia" (MINECO-ERDF, FEM2015-66937-P) and "The Animal Trope: An Ecofeminist Analysis of Contemporary Culture in Galicia and Ireland" (PGC2018-093545-B-I00, MCIU/AEI/FEDER, UE).

The process of edition of the present issue took place, to a significant extent, during the period of confinement forced by the Covid-19 pandemic, when academics were saturated with online classes, sundry telematic commitments and difficult access to library sources. Therefore, we want to express our most sincere gratitude to the readers who generously agreed to assess the submitted contributions, to the authors who diligently revised their manuscripts according to the indications received by the reviewers, and, most emphatically our gratitude goes to the former general editor of Estudios Irlandeses, Dr. José Francisco Fernández Sánchez who always encouraged and supported us, supervising our work from the very beginning, and patiently answering our endless e-mails.

This Covid-19 pandemic, which is still wreaking havoc around the world, has compelled even sceptics to rethink our relationship with nature and with the nonhuman animal world. On the one hand, the paradoxical effect of this sanitary tragedy has diminished consumption, reduced air pollution, altered mobility patterns and favoured our esteem of green spaces and rural areas. On the other hand, the appearance and spread of the Covid-19 virus should be taken as a warning against ecosystem alteration and human intrusion in wildlife habitats.

The articles included in this issue of Estudios Irlandeses study Irish writers' past and present engagement with Irish nature and with the representation and the condition of nonhuman animals in Irish culture. However, Irish authors, as the featured contributions show, also transcend local landscapes and translate their environmental concerns and their ethics of care beyond Irish frontiers, as is the case of Pearse Hutchinson and the writers in the collection Our Shared Japan. Women feature prominently both in the critical and in the creative sections, and this testifies to Irish women's early and enduring engagement with life on our planet.

This special issue begins with the article "Seven Types of Animality, Or: Lessons from Reading and Teaching Animal Fictions", by Roman Bartosch, in which the author puts forward seven significant lessons to be learnt from reading stories about human-animal encounters. The thought-provoking theoretical import of the article is balanced with a genuine effort to apply current debates in animal studies to the teaching of literature. The writing of Irish authors such as Jonathan Swift, Seamus Heaney and W.B. Yeats is analysed alongside that of other European writers in order to prove that the literary text, with all its complexity and ambiguity, is a privileged site for readers to make sense of more-than-human nature.

Alberto Lázaro Lafuente examines, in his article titled "The Representation of Jonathan Swift's Human and Non-human Animals in Spain", the reception and, especially, the Spanish translations of Book IV of Gulliver's Travels, considering the impact of such reception on the ecocritical significance of the book. The article argues that Swift's satire 
anticipates modern ecological questioning of the human-animal divide and that the Irish writer's configuration of anthropomorphic, rational horses on the one hand and, on the other, humanoid but animal Yahoos challenges claims of human exceptionalism.

The relationship between early feminist movements and antivivisectionism is the object of attention of the article "Frances Power Cobbe on Brutes, Women, and the Irish (Human) Landscape: Ethics, Environment, and Imperialism" by María José Carrera. This article examines the sundry intersections that involve national identity, class and gender in relation with the oppression of animals and women. In her discussion of Frances Power Cobbe's autobiography and essays, Carrera identifies a number of characteristic strategies that are common to the defence of women's and animals' rights in Cobbe's essays, but also exposes the contradictions that derive from Cobbe's Anglo-Irish background.

In her article "Alice's Garden: Imagining Agency in the Natural World in Clare Boylan's Black Baby", Maureen O'Connor has recourse to contemporary debates on biopower and geontopower to scrutinise the liminal states between life and death, the animate and the inanimate, the human and the nonhuman in Boylan's novel. O'Connor provides a fresh postcolonial analysis - informed by ecocriticism - of the Irish Roman Catholic Church missionaries in Africa and their impact on past and present racial configurations in Ireland.

The article "Medbh McGuckian and Ecofeminist Anxiety: "The Contingency of Befalling", by María Jesús Lorenzo-Modia, makes a very special contribution to the contemporary repertoire of Irish women's poetry by presenting a previously unpublished poem by Medbh McGuckian alongside its Spanish translation. Lorenzo-Modia enquires into the ecocritical value of elegiac poetry that engages, not only with aesthetic, but also with ethical, political and ecological concerns. This article conscientiously examines McGuckian's poetics of obliquity and lays bare its environmental and feminist thrust.

Auxiliadora Pérez Vides delves into the connections between detective fiction and dark ecology in her article "The Noir Landscape of Dublin in Benjamin Black's Quirke Series". The article argues that the urban landscapes of 1950s Dublin expose the complex, interrelated web deployed by the ethos of dominance. The author claims that the local specificity of the conflicts, the blurred demarcation between the familiar and the unfamiliar, the possibility that ugliness and horror might actually compel compassionate coexistence and, lastly, the animal and other tropes of nature used in this genre may actually open the way for an ecocritical reading of crime fiction.

The environmental import of Pearse Hutchinson's poetry is the object of Verónica Membrive Pérez's analysis in her article "Pearse Hutchinson's Ecopoetics on Spain (1950s1960s)". The article shows how the poet privileged the vernacular landscapes of Spain, with their historical and cultural specificity, over the "dehistorised spectacles" bolstered by Francoist "sun and sand" tourist propaganda. For Hutchinson, the article claims, environmentalism went hand in hand with social justice and, for this reason, he shunned the aesthetisation of the landscape.

The contribution by Arancha Rodríguez Fernández to this special issue, "Our Shared Japan: Contemporary Spaces of Love and Exoticism in Irish Women's Poetry", consists in the analysis of contemporary poetry by Irish women writers and their rendering of dislocation to critique traditional pastoralism. By using theoretical tools such as the notions of heterotopia, topoanalysis, ecogarden, post-pastoralism and tourist gaze, the author identifies the various ways in which the female authors featured in the anthology Our Shared Japan (De Angelis, and Woods 2007) conceive alternative female subjectivities through the experience of travel.

In the interview that Manuela Palacios and Luz Mar González-Arias conduct with the Irish writer Celia de Fréine - titled with the comment made by the writer: "Schoolchildren would not now be protesting had Greta Thunberg not made her stand. Writers have begun to take note" - the Irish author discusses her prolific career, with a special focus on her poetry 
and drama, and explains her standpoint regarding the current ecological crisis in Ireland and around the world. De Fréine is asked about the connection between biological and cultural diversity, especially when minority languages like Irish are at risk. The Irish author furnishes us with precious information about her writing and the way it engages with the multifarious connections between nature and literature, landscape and language, biological and cultural configurations of gender, rural and urban spaces that inspire literary production, the health and disease of human and nonhuman nature and the impact of the Covid-19 crisis on the Irish literary scene.

In her interview with the Irish writer Sara Baume - "An Artist, First and Foremost" Margarita Estévez-Saá enquires about the most pressing literary and social debates in Ireland in the last ten years, such as the arguable consideration of Irish women's fiction as confessional realism or the effects of the 2008 economic crisis and the Covid-19 pandemic on writing and publishing in Ireland, among other pertinent issues. In her answers, Sara Baume provides invaluable information about the social and personal conditions in which she has produced her writing and artistic work and reflects on the pressures, uncertainties and otherness concomitant of the artistic profession. Of special interest to this thematic issue is Baume's engaging discussion of the various manifestations of non-human nature in her artistic practice.

This special issue concludes with a critical selection of contemporary Irish poetry entitled "The Woman $\S$ Animal Trope", put together by the editors of the issue. In it, nine contemporary Irish women poets explore the relation between woman and animal by, among other diverse strategies, rewriting old myths and legends that used to link animal metamorphosis with patriarchal punishment or by turning to empowering animal tropes from mass culture, thereby contributing to current debates about the intersection of women's oppression and the exploitation of animal life, and about the tensions between vulnerability and empowerment.

Margarita Estévez-Saá is Senior Lecturer of English and American Literature at the Universidade de Santiago de Compostela. Her research interests include the work of James Joyce and, more recently, contemporary Irish fiction by women. She has published essays in which she studies the topic of immigration in recent Irish fiction, such as "Antidotes to Celtic Tiger Ireland in Contemporary Irish Fiction: Anne Haverty's The Free and the Easy and Éillís Ní Dhuibne's Fox, Swallow, Scarecrow" (2010) and "Immigration in Celtic Tiger and postCeltic Tiger Novels" (2013). She has also read contemporary novels in English from a transcultural perspective in "Trauma and Transculturalism in Contemporary Fictional Memories of the 9/11 Terrorist Attacks" (2016) and "Us returniks': Transcultural Atlantic Exchanges in Mary Rose Callaghan's and Elizabeth Wassell's Novels" (2018). More recently, she has co-edited with María Jesús Lorenzo-Modia the volume The Ethics and Aesthetics of Eco-caring: Contemporary Debates on Ecofeminism(s) (Routledge, 2019).

margarita.estevez.saa@usc.es

Manuela Palacios-González is Senior Lecturer of English at the University of Santiago de Compostela in Spain. She has directed five research projects on contemporary Irish and Galician literature that have been funded by the Spanish Ministry of Science, and has edited and co-edited several books in relation to this topic: Pluriversos (2003), Palabras extremas (2008), Writing Bonds (2009), Creation, Publishing and Criticism (2010), To the Winds Our Sails (2010), Forked Tongues (2012), Six Galician Poets (2016), Migrant Shores (2017) and 



publications include translations of European and Arabic poetry and fiction, a monograph on Virginia Woolf's pictorial imagery, Shakespeare's Richard III, and articles on ecocriticism.

manuela.palacios@usc.es

Noemí Pereira-Ares works in the Department of English, at the University of A Coruña. She graduated from the University of A Coruña in 2009 and received an MA in English Studies (2010) and a $\mathrm{PhD}$ in English Literature (2015) from the University of Santiago de Compostela. Her research interests include migrant literature(s) in English, postcolonial, diaspora and transcultural studies, and the sociological study of dress in literature. Her work has appeared in international peer-reviewed journals such as The Journal of Postcolonial Writing and Journal of Commonwealth Literature, and she has recently published a monograph entitled Fashion, Dress and Identity in the Narratives of the South Asian Diaspora: From the Eighteenth Century to Monica Ali (Palgrave Macmillan, 2018).

noemi.pereira@usc.es 